\title{
A Digital Heritage Best Practice from National Palace Museum: A Case of "Rebuilding the Tong-An Ships"
}

\author{
Kuo Chen Wo and Yang Yu Hsiang
}

\begin{abstract}
National Palace Museum (NPM) performed a series of new media art exhibitions in the Tongan tide exhibitions. The Project of "Rebuilding the Tong-an Ships" was starting from two diagrams of the Tongan Ship and related Qing archives; the research group begins a journey to salvage a long forgotten history. We used technologies such as building scale models, creating 3D models, and many other visualization tools to restore 19th century Southeast Asia's oceanic glories and disclose the Tong-an ships' multiple faces in its long history. This project have five goals: 1 . Building two scale models of the Tong-an ships at ratios of 1:30 and 1:20, based on Qing archival information; 2. Using 3D computer imaging techniques to create a real-life prototype model of the ship, which assembles and disassembles at will. The documentary details the process of creating this model, and relays the Tong-an ship's sea battles and historical legacy; 3. Inviting scholars and researchers gave touring lectures on campuses in order to promote the documentary, and to further advance educational awareness; 4 . Launching the NPM without Walls: Rebuilding the Tong-an Ships new media art exhibition powered by augmented reality and Microsoft Kinect technologies; 5. Compiling all products and publish a special publication in Chinese and English in order to document and spread the knowledge that we learned from the project of "Rebuilding the Tong-an Ships".
\end{abstract}

Index Terms-Digital art curation, digital curation, national palace museum, Tongan ships.

\section{INTRODUCTION}

Due to inherent limitations of the preservation and exhibition days are limited; the National Palace Museum (NPM) began to launch a series of huge heritage digital archives projects through National Digital Archives and e-Learning Technologies Plan, U-Taiwan Plan, etc. After a sound foundation, NPM then start a new media art exhibition show. Among these, an internet-based arts curation is the primary trial in the "NPM without Walls: Rebuilding the Tong-an Ships" new media art exhibition (July 20 September 22, 2013) at Taipei Huashan 1914 Creative Park is one of such art exhibitions. Among the digital artworks in the exhibition, new media arts applied internet technology to synchronize the exhibition show in the client sides to share the same venue exhibition with the server inside NPM.

The exhibitions began as a research project of Dr. Zhou Weiqiang, the curator. His study of NPM's Grand Council Archive's memorial attachments "Diagram of the Tong-an Ship Ji" and "Diagram of the Tong-an Ship No.1" results in

Manuscript received April 20, 2018; revised June 23, 2018.

Chen-Wo Kuo is with National Palace Museum, China (e-mail: paulkuo@npm.gov.tw).

Yu-Hsiang Yang is with YanCheng Teachers University, China (e-mail: yangyx@yctu.edu.cn)

doi: $10.18178 /$ ijssh.2018.8.8.965 very useful findings. With help from the Department of Education, Exhibition and Information Service, NPM have received grant from the "Phase Two of Development of Cultural and Creative Industries -- The Project of Providing a Cultural and Creative Platform for Bridging Science and Humanity" for the launching of "Rebuilding the Tong-an Ships" project.

It is becoming a developing trend for museums to use digital technologies to make exhibitions come alive.

This paper described the details of the "Rebuilding the Tong-an Ships", and it's main points of artworks to embodied the digital curation.

\section{RELATED WORKS}

\section{A. The Evolution Trend of Digital Application in Museums}

Museum (this refers to the physical museum) originates from A.D 290. Ptolemy Soter in Egypt built an Alexander museum to dedicate to Goddess-Muse. The museum collected mostly relics from the time when Alexander fought the wars in Europe, Asia, and Africa. These artifacts have over 2000year history. Therefore, the name "museum" is originated from "Mouseion." [1]

Traditionally, the function of museum is to preserve relics. However, through years of developments and under the definition from ICOM, museums nowadays have four basic core features: collect, display, research, and educate. Collection is not only to preserve valuable items, but to also include systemic registration, organization, and repairs; research is to identify, explain, and study the relic reserves as well as exhibits and education; exhibit needs to focus on the theme and further organize, analyze and design relics; lastly, education plays an important role in people's lifelong learning. After the 80s, new museum movements based on human brought new influences. The varieties of museum and management methods are different from before, but museum still plays the role of cultural facility in the society. Therefore, regardless of what ways to manage the museum, it needs to focus on the changing trend of world culture and promote social development.[2]

Following the development of computers and the internet, museums also move toward the digital world. Besides the impact of the digital world, the budget cut is also one of the reasons to redefine museum. Digital museum can certainly spread the information all over the world - as, for example, online news would - in order to achieve the strategy of market expansion.

The digital application trend in museum can also be seen in museum reviews. "The Calligraphic World of Mi Fu's Art" 
website made by National Palace Museum (NPM) in 2006 won the golden medal on the Online-Presence of MUSE Awards from American Association of Museums in 2007. MUSE Award is the annual award under Media and Technology Committee part of Standing Profession Committees in American Association of Museums. The $\mathrm{M} \& \mathrm{~T}$ is responsible for connecting the American Association of Museums to media technology in order to match audiences' demands [3]. The Online-Presence Award is a newly founded award in 2007. In fact, the MUSE Award will set up different categories based on the trends at the time. Therefore, we could conclude that there is a close relationship between museum trends and the developments of technology.

\section{B. Digital Arts}

Digital art is an artistic production or work by using digital technology as an important part of the creative or presentation process. After some struggling, the impact of digital technology has transformed activities such as painting, drawing, sculpture and music/sound art, while new forms, such as virtual reality, augmented reality, and immersive technologies, have become recognized artistic works. In a broad sense, "digital art" is a term applied to contemporary art that uses the methods of mass production or digital media [4]. Digital art can be purely computer-generated (such as fractals and algorithmic art) or taken from other sources, such as a scanned photograph or image drawn using vector graphics software using a mouse or graphics tablet. Though technically the term may be applied to art done using other media or processes and merely scanned in, it is usually reserved for art that has been non-trivially modified by a computing process (such as a computer program, microcontroller or any electronic system capable of interpreting an input to create an output); digitized text data and raw audio and video recordings are not usually considered digital art in themselves, but can be part of the larger project of computer art and information art. Artworks are considered digital painting when created in similar fashion to non-digital paintings but using software on a computer platform and digitally outputting the resulting image as painted on canvas [5].

\section{Digital Curation}

The term "curator" self comes from Latin, originally used in the field of cultural heritage, planning, screening and display of art exhibition activities in the design, organization and management. In fact, the digital curation is hot only in recent years. However, the appearance of the term "digital curation" can be traced back to 2001, in the seminar "Digital Curation: Digital Archives, Libraries and e-Science" sponsored by the Digital Preservation Coalition and the British National Space Center [6]. Digital curation is the active management and enhancement of trusted digital resources across the life cycle. It usually encompasses both data curation and digital preservation activities. OAIS Model (refer to Fig. 1) describes the environment, functional components and information objects within a preservation system. Its major contribution is that it specifies terminology (e.g. Submission Information Package (SIP), Archival
Information Package (AIP), and Dissemination Information Package (DIP)), concepts and a workflow model of how data moves through a repository, from ingest to management within the repository to how it is provided to users [7].

In the language of digital curation, a digital achieving system is not just any data storage system, but also the intention of long-term use of data in accordance with the archival principles of authenticity, integrity and provenance of data. Digital curation embodies the archival concepts needed for long-term preservation and access.

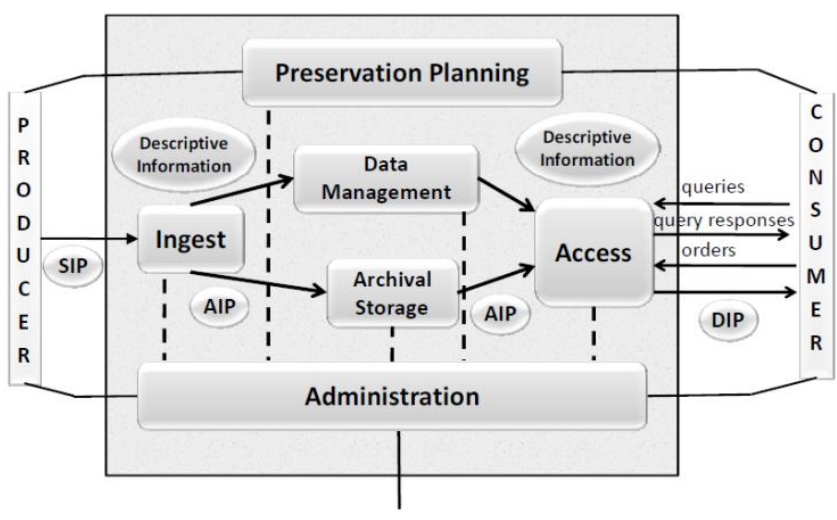

MANAGEMENT

Fig. 1. OAIS functional entities [7] [SIP=Submission information package; $\mathrm{AIP}=$ Archival information package; $\mathrm{DIP}=$ Dissemination information package]

\section{The Project of "RebuILdIng The Tong-An SHIPS"}

\section{A. The Historical Study of the Tong-an Ships}

Diagram of the Tongan Ship Ji "and "Diagram of the Tongan Ship No. 1", both owned by the NPM, are the key historical pictorial data for our research. They described the heaviest and most powerful two classes of Tong-an fighting ships. They are also very special because they contain formerly unknown details and these evidences are collaborated by official memorials and other texts. They are not only very unique collected items for museum. They lead us to an unexplored area of the history of oceanic exploration and Taiwan studies.

Tong-an Ships as Merchant Ships, Fighting Ships and Pirate Ships [8].The two key issues about the historical study of Tong-an ships are reconstruction of their activities and valuation of their importance. We can see their great contributions to Qing's coastal defense. Tong-an ships were merchant ships first built in Tong-an, Fujian. They were widely seen off the coasts of Fujian and Zhejiang. As late as late 18 th century, they were already used off the coast of Zhejiang to fight pirates.

The Project of "Rebuilding the Tong-an Ships" was starting from two diagrams of the Tongan Ship and related Qing archives; the task group begins a journey to salvage a long forgotten history. We used technologies such as building scale models, creating 3D models, and many other visualization tools to restore 19th century Southeast Asia's oceanic glories and disclose the Tong-an ships' multiple faces in its long history. This scholastic work, when transferred to the screen, employed the building of a wooden scale model 
and rendering of 3D imagery to supply its footage. The finished documentary is fifty minutes long and consists of three acts.

\section{B. Building a Wood Model Ship for Structure Test and Creating a 3D Computer Model}

To increase educational value, we have built a 3D model of the Tong-an ship in order to facilitate future developments. Not only we can keep on developing interactive software, we saved a lot money on actually rebuilding and maintaining the ship. This is a cost efficient way to revitalize historical technologies.

As a new sea-worthy ship developed since mid-Qing era, Tong-an ships were used not only by merchants, but also by the pirates. In the end, they became the backbone of Qing navy's fighting power. They were built in great numbers. They were customized for various purposes. Qing stationed them from the Bohai Sea to Taiwan. Before the invention of steam-powered ships, they were the zenith of Chinese wooden sailing vessel's development [8].

To let us fully comprehend Tong-an ship's internal construction, the task team supplies Tong-an ship's specifications obtained from historical sources and let experienced ship model technician Tseng Shu Ming to build the Tong-an ship model for us. There are four steps: building the structure test model, drafting the ship blueprint, making the sailing test model, and making the display model.

The first step is making the structure test model. We used the historical Tong-an ship "Ji" data obtained from the "The Tung-an Shuttle Junk 'Ji' Diagram" and another related ship, the Ganzeng ship's data, compartment layout and deck layout obtained from the "Illustrations of the Ships of Fujian Province's All Naval Bases", and then adjusted these numbers based on the Tong-an ship's properties to compile the final specifications. Then we draft the blueprint and build the structure test model in order to see if the historical data contains discrepancies or errors, or if the compartment and deck layouts are infeasible. When the structure test model is completed, the task team approves the design; we draft the restored deck layout and create the final blueprint. In the end, we generate an AutoCAD file from the finalized design.

In addition to strictly adhere to historical specifications, we still have to test and make sure the ship is really sea-worthy. The technician builds a 1/30 sailing test model and took it to the Dahu Park of Neihu, Taipei for tests. Except for a radio controlled rudder, the test model is only powered by its sails. The tests show the model is sea-worthy.

To allow easy transportation, maintenance, building and displaying, the display model is set to be $1 / 20$ in scale. In order to be configurable during display, the masts, sails, rudders, guns, hatches, gates, gun ports, and gun seats are all movable. We also have built accessories such as cannonballs, gunpowder barrels, soldiers, flags, and cables. Finally, the display model is detailed and painted. The coloring scheme is true to the original colors of the "The Tung-an Shuttle Junk 'Ji' Diagram". However, the model's coloring must be adjusted to compensate for the fading of the aged inks.

After the ship's AutoCAD model is completed, it is given to the $3 \mathrm{D}$ effects house to convert to the 3DS Max format. Then we render images of TGA format. In the end, we use

\section{Fusion and Adobe after Effects for post-production.}

\section{Making Documentary Film of the Tong-an Ship}

The documentary film is consists of parts such as reenactments, scholar interviews, location shootings and 3D computer graphics. For reenactments, we used a number of film-making techniques to keep the costs down without sacrificing the required sense of epic. Due to limited budgets, we cannot afford to build full-sized sets for the required scenes such as the pirate's den, pillaging, sailing and sea battles. As a result, the director used green screen photography to film the actors and then compose the final image using computer-generated background elements. We used 4k-resolution RED cinema cameras for principal photography. Then we used Fusion and Adobe after Effects for post-production. The final output is then color graded in order to correct each shot's color.

Act one explains the historical background of the Tong-an ships' rise. It contains a reenactment of the deadly sea battle between Li Changgeng, the Provincial Commander of ZhejiangandCai Qian, a pirate [8]. It then shows the establishment of Qing's Tong-an ship fleets. Act Two elaborates the restoration of Tong-an ships. We see how the task team digs deep inside historical records to learn about the two-hundred-year-old Chinese sailing ship and how the craftsman builds the 1/20th model of the Tong-an ship. In Act Three, we analyze the Tong-an ship's main structure and design using 3D visualization technologies.

Due to very limited historical sources, it is a very difficult job to restore a complex engineering such as this. By studying the "Illustrations of the Ships of Fujian Province's All Naval Bases", we finally learned much about the lost details of the National Palace Museum's two Tong-an ship diagrams [8]. After countless times of discussions between the task team and the ship modeler, we finally drafted the three views of the Tong-an ship and used these diagrams as the basis of our restoration.

\section{Social Education and Promotion}

As to educational promotion, we arranged the premiere press conference, campus tour and the publication of a Chinese and English bilingual special publication. Regarding the premiere press conference, we setup an official Rebuilding the Tong-an Ships website in order to supply people first hand information about this project. Additionally, we have signed a public broadcasting contract with the Taiwan Public Television Service (PTS). We also uploaded the teasers and trailers to YouTube and setup a Facebook community as our mass viral marketing. These steps are the prelude to our February 21, 2013 premiere press conference. A great number of journalists, scholars and experts attended the press conference on that day. After the press conference, we were reported by many newspapers and news channels. Our first step of promotion was very successful. The news about the NPM's documentary Rebuilding the Tong-an Ships was reported or syndicated by more than one hundred news media.

Since our premiere was highly acclaimed by the media and the academia, the NPM production team starts to launch a series of campus tour. Our target audience is from pupils of 
fifth grade or higher to liberal arts major college students. Multimedia and interactive system-related students are also included. Our lecturers not only include scholars of Qing history, maritime history and the history of science and technology, we also have arranged artists, such as documentary director, 3D special effects and post-production technicians and movie scoring composers to meet the audience face to face and share their knowledge and experience with the students.

Since additionally, we publish a Chinese-English bilingual special publication for people who are interested in our project. We wrote down our project's history so we can share the experience and knowledge that we learned during the Tong-an Ship's restoration research. The special publication, which is this book, presents the fruits of the documentary Rebuilding Tong-an Ships from cultural creative and historical points of view. Our promotional efforts successfully expanded the sphere of influence of the project Rebuilding the Tong-an Ships. We may safely say that it is just the beginning of a glorious age of the Tong-an ship's digital heritage second life.

\section{E. Launching the Tong-an Ships New Media Art Exhibition}

The NPM without Walls: Rebuilding the Tong-an Ships new media art exhibition (July 20 - September 22, 2013) at Taipei Huashan 1914 Creative Park is a great companion to the Voyage with the Tailwind: Qing Archival and Cartographical Materials on Maritime History exhibition in NPM. In addition to playing the documentary and displaying the $1 / 30$ wooden structure test model ship, we have designed several digital exhibitions. The multi-sense experiences of this exhibition provide visitors a new way to see an exhibition.

As to the digital exhibition, at first, we reuse the documentary's 3D ship model part to generate a short clip of naked-eye 3D visualization. Secondly, we use augmented reality (AR) and Microsoft Kinect technologies to provide the visitors an immersive ship sailing experience. Thirdly, we build a sea chart interactive table powered by multi-resolution and multi-finger sensor technologies to allow visitors to see a coastal defense map at desired magnification or appreciate artwork related to the Tong-an ship. Fourthly, we setup a cloud-based digital gallery which can be remotely updated for the location in order to present related information to visitors. As to multisensual input, we spray refreshing scents of the sea and play recording of wave breaking sound within the exhibition. This enables us to create a multi-sensual surrounded environment that helps visitor to enter the world that we created and enjoy the exhibition in an immersive manner.

As to educational activities, NPM designed a Build Your Own Tong-an Ship with Your Hands educational promotion course. We have hired a paper sculpture artist, to design a 3D paper model of the Tong-an ship and teach our family visitors to make the model at the exhibition. By building the model by hand, visitors can see the ship's structure with their eyes and learn much about the ship. Building the ship by hand is also very rewarding. This activity also provides a good way for parents to work with their children. This activity strengthens visitors' interaction with the NPM without Walls: Rebuilding the Tong-an Ships new media art exhibition. It also makes the word Rebuild literal and more meaningful. This kind of activity builds connections between the visitor and the artifact. This is not just a new way to look at history, it also allows a long gone and forgotten to be revitalized in a new and very different form.

\section{VISITOR EXPERIENCE}

Held in the Boiler Room at Huashan 1914 Creative Park, the exhibition ran from July 20 to September 22, 2013. The Park closes on Mondays. Weekends and holidays crowds peak (Table I). Total attendance reached 54,067 visitors. The highest percentage visiting group falls in the 20-29 age range (Table II), with more female than male visitors (Table III); sex and age factor little into overall satisfaction, but familiarity with electronic equipment has a significant difference on visitor response (Table IV), indicating that this exhibition is immensely suitable for the internet generation and corresponds to curatorial objectives.

The overall satisfaction rating for this exhibition is $99.4 \%$ (Table V). The most popular exhibition piece is Breaking Waves: Tongan Ship Interactive Game, with $35.1 \%$ average satisfaction rating (Table VI); The satisfaction rating for the hardware equipment is $87.9 \%$ ( Table VII).

TABLE I : EXHIBITION VISITORS BY DAYS OF THE WEEK

\begin{tabular}{lccccc}
\hline \hline \multirow{6}{*}{} & & Frequency & Percentage & $\begin{array}{c}\text { Effective } \\
\text { Percentage }\end{array}$ & $\begin{array}{c}\text { Cumulative } \\
\text { Percentage }\end{array}$ \\
\hline \multirow{6}{*}{ Efficient } & Tuesday & 207 & 12.9 & 13 & 13 \\
& Wednesday & 198 & 12.4 & 12.4 & 25.3 \\
& Thursday & 232 & 14.5 & 14.5 & 39.9 \\
& Friday & 284 & 17.8 & 17.8 & 57.6 \\
& Saturday & 381 & 23.8 & 23.8 & 81.5 \\
& Sunday & 296 & 18.5 & 18.5 & 100 \\
Missing & Total & 1598 & 99.9 & 100 & \\
Values & System-Missing & 2 & 0.1 & & \\
& Values & & & & \\
& Total & 1600 & 100 & & \\
\hline \hline
\end{tabular}

TABEL II: EXHIBITION VISITORS DISTRIBUTED BY AGE

\begin{tabular}{|c|c|c|c|c|c|}
\hline \multicolumn{2}{|c|}{ Age } & Frequency & Percentage & $\begin{array}{c}\text { Effective } \\
\text { Percentage }\end{array}$ & $\begin{array}{l}\text { Cumulative } \\
\text { Percentage }\end{array}$ \\
\hline \multirow{5}{*}{ Efficient } & $<20$ & 342 & 21.4 & 21.4 & 21.4 \\
\hline & $20 \sim 29$ & 572 & 35.8 & 35.9 & 57.3 \\
\hline & $30 \sim 39$ & 288 & 18 & 18.1 & 75.4 \\
\hline & $40 \sim 49$ & 298 & 18.6 & 18.7 & 94 \\
\hline & $>50$ & 95 & 5.9 & 6 & 100 \\
\hline \multirow{3}{*}{$\begin{array}{c}\text { Missing } \\
\text { Values }\end{array}$} & Total & 1595 & 99.7 & 100 & \\
\hline & $\begin{array}{c}\text { System } \\
\text { Missing } \\
\text { Values }\end{array}$ & 5 & 0.3 & & \\
\hline & Total & 1600 & 100 & & \\
\hline
\end{tabular}

TABEL III: EXHIBITION VISITORS DISTRIBUTED BY GENDER

\begin{tabular}{cccccc}
\hline \hline \multicolumn{1}{c}{} & & Frequency & Percentage & $\begin{array}{c}\text { Effective } \\
\text { Percentage }\end{array}$ & $\begin{array}{c}\text { Cumulative } \\
\text { Percentage }\end{array}$ \\
\hline \multirow{3}{*}{ Efficient } & Female & 1100 & 68.8 & 68.8 & 68.8 \\
& Male & 498 & 31.1 & 31.2 & 100 \\
& Total & 1598 & 99.9 & 100 & \\
Missing & System & & & & \\
Values & Missing & 2 & 0.1 & & \\
\multicolumn{2}{c}{ Total } \\
& Values & & & & \\
\hline \hline
\end{tabular}


TABEL IV: THE EFFECT OF GENDER ON OVERALL SATISFACTION DATA Group Statistics

\begin{tabular}{|c|c|c|c|c|c|}
\hline \multicolumn{6}{|c|}{ Group Statistics } \\
\hline \multirow{3}{*}{ Total } & Gender & Frequency & Mean & $\begin{array}{l}\text { Standard } \\
\text { Deviation }\end{array}$ & $\begin{array}{c}\text { Standard } \\
\text { Error of the } \\
\text { Mean }\end{array}$ \\
\hline & Female & 1078 & 4.1313 & 0.42458 & 0.01293 \\
\hline & Male & 487 & 4.1471 & 0.41111 & 0.01863 \\
\hline \multicolumn{6}{|c|}{ TABEL V: OVERALL SATISFACTION } \\
\hline & & Frequency $P$ & Percentage & $\begin{array}{c}\text { Effective } \\
\text { Percentage }\end{array}$ & $\begin{array}{l}\text { Cumulative } \\
\text { Percentage }\end{array}$ \\
\hline \multirow{4}{*}{ Efficient } & $\begin{array}{c}\text { Very } \\
\text { Satisfied }\end{array}$ & 383 & 23.9 & 24.1 & 24.1 \\
\hline & Satisfied & 1045 & 65.3 & 65.7 & 89.8 \\
\hline & Neutral & 163 & 10.2 & 10.2 & 100 \\
\hline & Total & 1591 & 99.4 & 100 & \\
\hline $\begin{array}{l}\text { Missing } \\
\text { Values }\end{array}$ & $\begin{array}{l}\text { System } \\
\text { Missing } \\
\text { Values }\end{array}$ & 9 & 0.6 & & \\
\hline \multicolumn{2}{|c|}{ Total } & 1600 & 100 & & \\
\hline
\end{tabular}

TABEL VI: FAVORITE EXHIBITION ITEM

\begin{tabular}{|c|c|c|c|c|c|}
\hline & & Frequency & Percentage & $\begin{array}{c}\text { Effective } \\
\text { Percentage }\end{array}$ & $\begin{array}{l}\text { Cumulative } \\
\text { Percentage }\end{array}$ \\
\hline & The "Bon & & & & \\
\hline & Voyage" & 225 & 14.1 & 14.1 & 14.1 \\
\hline & Projection Wall & & & & \\
\hline & $\begin{array}{l}\text { Cross-over } \\
\text { Dialogue: }\end{array}$ & 228 & 14.3 & 14.3 & 28.4 \\
\hline & Cloud Gallery & 65 & 4.1 & 4.1 & 32.5 \\
\hline & $\begin{array}{l}\text { Deconstructing } \\
\text { the Tongan } \\
\text { Ship }\end{array}$ & 140 & 8.8 & 8.8 & 41.2 \\
\hline & Looking & & & & \\
\hline & Through the & 65 & 4.1 & 4.1 & 45.3 \\
\hline & Tongan Ship & & & & \\
\hline Efficient & The AR Clothes & & & & \\
\hline & $\begin{array}{l}\text { Changing } \\
\text { System }\end{array}$ & 124 & 7.8 & 7.8 & 53.1 \\
\hline & $\begin{array}{c}\text { Breaking } \\
\text { Waves }\end{array}$ & 561 & 35.1 & 35.2 & 88.2 \\
\hline & The Nautical & & & & \\
\hline & $\begin{array}{c}\text { Chart } \\
\text { Interactive }\end{array}$ & 51 & 3.2 & 3.2 & 91.4 \\
\hline & Tabletop & & & & \\
\hline & Rebuilding the & & & & \\
\hline & $\begin{array}{c}\text { Tongan Ships: } \\
\text { Theater }\end{array}$ & 137 & 8.6 & 8.6 & 100 \\
\hline & Total & 1596 & 99.8 & 100 & \\
\hline $\begin{array}{l}\text { Missing } \\
\text { Values }\end{array}$ & $\begin{array}{c}\text { System Missing } \\
\text { Values }\end{array}$ & 4 & 0.3 & & \\
\hline & Total & 1600 & 100 & & \\
\hline & TABEL VII: SAI & ( & Н ПАКУV & AKE LQU & IENT \\
\hline & & Frequency & Percentage & $\begin{array}{c}\text { Effective } \\
\text { Percentage }\end{array}$ & $\begin{array}{l}\text { Cumulative } \\
\text { Percentage }\end{array}$ \\
\hline & Very Satisfied & 433 & 27.1 & 27.2 & 27.2 \\
\hline Efficion & Satisfied & 964 & 60.3 & 60.6 & 87.9 \\
\hline Efficient & Neutral & 193 & 12.1 & 12.1 & 100 \\
\hline & Total & 1590 & 99.4 & 100 & \\
\hline Micsing & System & & & & \\
\hline $\begin{array}{l}\text { Missing } \\
\text { Values }\end{array}$ & $\begin{array}{l}\text { Missing } \\
\text { Values }\end{array}$ & 10 & 0.6 & & \\
\hline & Total & 1600 & 100 & & \\
\hline
\end{tabular}

\section{CONCLUSION}

The Tong-an ship, which dominated the first part of the 19th century, represented the acme of Chinese sailing ship art and technology. However, the rise of modern steam ships rendered these traditional ships obsolete. They became a part of the history. Having spent two years on literature research and four months of filmmaking, the documentary Rebuilding the Tong-an Ships premieres on February 21, 2013. The news coverage of the show and internet promotion brings us even more good news. Many schools, museums and cultural institutions contact us for purchasing and/or asking for speeches. To meet public demand, the NPM decides to launch a campus tour to share historical knowledge and our filmmaking experiences with students.

Based on the news coverage of the show and internet promotion brings us even more good feedbacks. The project is to be considered as a best practice for how to use the digital heritage in the museum even though we do not have the enough budget and time to compete with real business movies, we still hope that we can make very good use of our museum's collections, our researchers group bring more inspiring stories to audience and the knowledge that we learned from the project of "Rebuilding the Tong-an Ships". Through the solid historical studies, we have made a documentary and built a physical model and another 3D computer model of the Tong-an ship. We have taken the audience back to a time period that was forgotten and the Tong-an ship's historical meanings to them.

\section{REFERENCES}

[1] N. S. Ansher. (2011). Understanding museums and art galleries: Commonalities and Differences. [Online]. Available: https://www.academia.edu/1085332/Understanding_Museums_and_A rt_Galleries_Commonalities_and_Differences

[2] V. Ginsburch and F. Mairesse, "Defining a museum: suggestions for an alternative approach," Museum Management and Curatorship, vol. 16, no. 1, pp. 15-33, 1997.

[3] L. Pujol-Tost, "Integrating ICT in exhibitions," Museum Management and Curatorship, vol. 26, no. 1, pp. 63-79, 2011.

[4] C. Paul, Digital art. 2003, London: Thames \& Hudson.

[5] L. Mamykina, L. Candy, and E. Edmonds, "Collaborative creativity," Communications of the ACM, vol. 45, no. 10, pp. 96-99, 2002.

[6] N. Beagrie, "Digital curation for science, digital libraries, and individuals," International Journal of Digital Curation, vol. 1, no. 1, pp. 3-16, 2008.

[7] J. CCSDS, "Reference model for an open archival information system (OAIS)," CCSDS 650.0-B-1, Blue Book, 2002.

[8] W. Q. Zhou, "Historical investigation and technological presentation of the rebuilding the Tongan ships," Documentary, The National Palace Museum Monthly of Chinese Art, vol. 361, pp. 96-109, 2013.

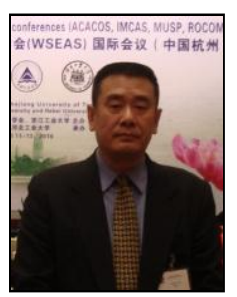

Chen-Wo Kuo is the Section Chief of Dept. of Book and Documents in National Palace Museum, Taipei. $\mathrm{He}$ is also an adjunct professor which teaches the classes about the digital archives and designs in the National Taiwan University of Arts. With the experiences in dedicating the new media arts exhibitions for National Palace Museum and winning appraises from professionals and visitors, he mainly focuses in exploring the new technologies in new media arts field to a reference. Current and previous research interests end the paragraph.

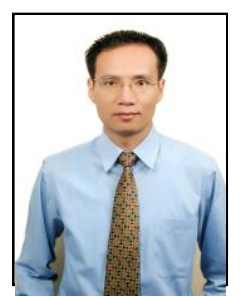

Yu-Hsiang Yang is an associate professor of Dept. Finance at Yan Cheng Teacher University. He earned a Master of Business Administration degree infinance and Ph.D degree in Management Information Systems fromNational Chengchi University. In addition to his interest of IT studies, he also obtained another master degree in Buddhist studies atChung-Hwa Institute of Buddhist Studies. Herewith the interests of agenttechnology, finance, investment and big data, he has focused on Gamification in Education. 